\title{
Enabling Psychosocial Environment for Effective Technology Education: Implications for Youth Empowerment
}

\author{
Ezeudu F. O., Eskay Michael \\ University of Nigeria, Nsukka, Nigeria
}

\begin{abstract}
Education is an instrument of change. The society looks on education for its improvement. The National Policy on Education aims at meeting the national needs and objectives. The issues of whether the needs and objectives of this nation can be achieved technologically by the youths are a question to be answered by this paper. Meanwhile, the paper investigated the existing Technology Education Institutions' psychosocial factors for empowering the youths with and without special needs with a view to establishing the possible relationship it may have with their performance. The study focused specially on FCEE (Federal College of Education, Eha-Amufu) for the proximity. One research question was used and one hypothesis was tested at the 0.05 alpha level of significance. The results showed no significant relationship between the psychosocial environment and youth empowerment. The implication of the study is that greater attention should be paid to the physical and social environment of the Technology Education Institutions so as to enhance youth empowerment with or without special needs, which will motivate them to be self-employed and be able to solve national problems.
\end{abstract}

Keywords: special education, science and technology education, youth empowerment, technology education institution, psychosocial environment, teaching, Infrastructural facilities, and self-employment

\section{Introduction}

Education is for social reconstruction (Ukeje, 1966). Education can be a powerful instrument for changes at both the societal and the individual levels. It is the driving force in economic and social development. It is our only hope to improve our society. Social changes depend on the science and technology education and its level of development also depends on the level of science and technological development. Technology is the application of the ideas of science in solving practical problems in the society. According to New Standard Encyclopedia, technology is the use of scientific knowledge to develop and produce goods and services useful to man. A national level of technology depends on the extent to which scientific knowledge is put to practical use. Technology offers employment for self-reliance and self-dependence. It provides self-technological knowledge for everyday living. It equips the individuals to acquire skills in the use of tools and equipment. Nwokolo (2002) defined technology education as a means by which man controls and modifies his environment. All these show that the importance of technology education in the society cannot be over-emphasized. It is, therefore, pertinent to say that technology education should produce youths who should design, manufacture, sell, commission, maintain, and use the products of technology. Youths are children 
between childhood and adulthood. They are in the important era of total life span. They are in the period seen as the spring of life of human beings. Education is the greatest empowerment agent. An educated youth is empowered economically, politically, and intellectually in every aspect of life. Technology education will provide them with more gainful employment and enhance their socio-economic standing.

\section{Psychosocial Facilities That Make for a Conducive Technology Education Institution Environment}

For the youth to be empowered technologically, the psychosocial facilities must be available and the environment must be conducive. Some of the psychosocial facilities are:

(1) Infrastructural facilities: For technology education to be impacted on the youths, there must be infrastructural facilities, such as the classroom blocks, hostels, libraries, reading spaces, books, charts, instructional materials, administrative blocks, offices for the lecturers and playgrounds;

(2) Laboratories: Good laboratories provide conducive environment for technology education. The youths can be empowered technologically if there is equipment and chemicals in the laboratories. There is no course in N.C.E. institutions that does not need adequately equipped laboratory;

(3) The infrastructural facilities and the laboratories must be in conformability: There must be adequate scats, tables, beds, fans, etc.. Overcrowded classrooms or hostels deny the youth the comfort needed for technology acquisition.

For the youths to be empowered technologically, there must be motivations, something propelling them to respond to technology education teachings. This motivation must be intrinsically in the sense that they are internally generated and extrinsically that is externally generated by physical activities;

(4) Scientific displays: The classrooms must be that which motivate good learning environment for the youths. The youths must be involved in whatever goes on in the classroom. The activities in the classroom must be challenging, interesting, and attractive and they should be one in which the youths must participate fully. Desks, chairs, charts, technological materials, equipment, and the total classroom atmosphere must motivate the youth. Democracy, competitiveness, and rule clarity must be observed in the classrooms. Good teacher-youth interaction must be fostered;

(5) Teaching: Teachers approach and techniques of teaching could go a long way to empower the youths technologically, and the task must be spelt out. Good teaching methods must be employed. Active youth involvement must be in all the activities. The teachers must employ creation of competitive environment for technological growth. The teachers must be models the youths can emulate. Their actions, thinking, and behaviours must be appealing to the youths.

The college environment must be the one that empower the youths technologically. There should be good administration-staff relationships, teachers-youth interactions and administration-youth relationships. Formal order and organization must be spelt out every day to the youths. The youths must be given free hand in the running of their unions. Rules and regulations in the libraries, laboratories, classrooms, hostels, etc., must be maintained because it promotes conducive atmosphere for Technology Education for the youths. Professional interests must be encouraged. The college could organize seminars and workshops based on Technology Education for the youths and the teachers.

\section{Problem}

The students at the College of Education are youths who have passed through the secondary school education but are now receiving training that will equip them to function properly in the society. The nation has 
high national debt and there is absence of a solid capital base, which tends to put a strain on the available educational resources. The resultant effect is that the necessary facilities needed to equip these youth with proper education for them to technologically carry this nation to modern light are lacking. More so when these youths graduate from the College of Education, they have no jobs. Most unfortunately, many of them cannot engage in any meaningful job that will help them to be self-reliant. So, the issue of whether the technology education institutions really empower the youths is a question that should be answered by this paper:

(1) Research question: To what extent does the psychosocial environment of the technology education institutions affect the youth empowerment technologically?

(2) Research hypothesis Ho1: There will be no significant relationship between the psychosocial environment and the youth empowerment technologically.

(3) The focus: The study focused on the psychosocial environment. The findings of this study, hopefully, would assist lecturers and the college management to adjust the set goals and objectives as well as look at some psychosocial facilities and to provide some that are not available. The significance of the study, which resulted from the answered research question and hypothesis, was established. The study proved that there is significant relationship between the college environment and the youth empowerment. The implication is that technology education institutions should re-visit the psychosocial environment so as to enhance the youth for effective acquisition of technological skills needed for national growth and economic stability.

\section{Methodology}

\section{The Design}

This study is a simple survey. It involves getting the opinion of the youths and using the information to assert if the technology education institutions have enough psychosocial facilities to empower the youths technologically.

\section{Area of Study}

FCEE (Federal College of Education, Eha-Amufu), Enugu State, was chosen for the study.

\section{The Population of the Study}

The target population for this study was all the students in FCEE.

\section{Sample and Sampling Technique}

There are 23 academic departments in FCEE, 20 students per department were sampled from 200 and 300 levels, using the stratified random sampling techniques to cater for the different subject combinations. The total number of students used was 460 .

\section{The Instrument for Data Collection}

The major instrument for data collection was structured questionnaire. The questionnaire was prepared for the students. It was prepared and administered by the researcher. To ensure that the items in the questionnaire were valid, the draft copies of the questionnaire were given to colleagues in the college and also to some measurement and evaluation experts to validate. After intensive and objective critics, the corrections were made and 40 items were retained. Four point likert type of scale was used for the study. The weighting ranged from "SA (Strongly agree)" = 4 points, “A (Agree)" = 3 points, "D (Disagree)" = 2 points, and "SD (Strongly disagree)" = 1 point. It is reversed when the item in the questionnaire is negative. The students reacted to the 
items in the questionnaire.

\section{Method of Data Analysis}

Means and SDs (standard deviations) scores were used to answer the research question while the $t$-test statistic was used to test the null hypothesis.

\section{Results and Findings}

From Table 1, a large number of youths 310 (67.40\%) strongly agreed that the psychosocial environment within college was inadequate to enable them to receive technology education. A total of 106 (23.04\%) agreed that the psychosocial environment was inadequate for promoting youths.

However, 15 (3.26\%) strongly disagreed that the environment is inadequate.

Table 1

Summary of the Responses of the Students on the Items of the Questionnaire

\begin{tabular}{lcc}
\hline Criterion & Number & Percentage (\%) \\
\hline SA & 310 & 67.40 \\
A & 106 & 23.04 \\
D & 29 & 6.30 \\
SD & 15 & 3.26 \\
Total & 460 & 100.00 \\
\hline
\end{tabular}

Table 2

Responses of the Students to the Psychosocial Environmental Questionnaire

\begin{tabular}{llllllll}
\hline Variable & $N$ & $X$ & $S D$ & $d f$ & T0cal & $t$-table & Decision \\
\hline & 460 & 80.67 & 5.71 & 458 & 16.87 & 1.96 & $\mathrm{~S}$ \\
\hline
\end{tabular}

Note. $\mathrm{S}=$ Significant at $0.05(p<0.05)$ level of probability.

Analysis of responses in Table 2 shows positive response from the overall mean. The mean sore (80.67) is high, therefore, hypothesis, which states that there is no significant relationship between the psychosocial environment and youth empowerment is technologically upheld.

The calculated $t$-value of 16.87 is greater than the table $t$-value of 1.96 at 0.05 level of significance. Therefore, the null hypothesis was accepted. That is, there is significance difference between the psychosocial environment and youth empowerment technologically.

This finding confirms that the psychosocial environment in our tertiary institutions does not promote youth empowerment technologically. This study revealed that the materials needed to empower the youths technologically are not available. The result also implied that the college authority does not show keen interest in providing those important materials. Good physical environment makes learning pleasurable. The absence of these hinders the youths from getting enough technology education needed for self-sustenance on graduation.

\section{Discussion of Findings}

The findings of the study showed that psychosocial facilities available at the technology education institution are not enough to empower the youths. Majority of the youths responded that the infrastructural facilities needed for technological acquisition are lacking. Onwuka (1989) commented that the teachers cannot work without equipment. The youths cannot be empowered technologically without infrastructural facilities. 
The hostels, classrooms, libraries, laboratories, etc., must be that which will provide enabling environment for technology impart on the youths. The classroom interaction will provide enabling environment for technology impart on the youths. The classroom interaction which the youths disagreed is not motivating, challenging and interesting reflected other works done by Bonjuwoye (1985) who reported that the Nigerian classrooms have poor instructional facilities. One then wonders how the youths can be empowered at these classrooms where most of them stood up to receive lectures. A large number of students in the classroom do not promote good teacher-student interaction and motivation. Lack of role-play and other activities that promote technology education are lacking. Some lectures with dubious behaviours, who engage on purchase of textbooks before passing assignments and other fetish behaviours constitute hindrance to technology empowerment to the youths. Unless such activities are addressed in our Technology Education Institution, the youth will continue to suffer. Unemployment is also a hindrance to youth's empowerment technologically. There is nothing as discouraging as uncertainty for the future. Unless the quality of technology impacted to the youths are improved and proven to provide them with future employment, all the effects geared towards technology education empowerment to the youths will be in vain.

\section{Recommendations}

To increase the quality of technology education facilities so as to produce the youths that will meet societal and labour market's demands. The LGA (federal, state, and local government) and NGOs (non-governmental agencies) should increase funding of technology education. They should provide loans, scholarships, and national technology education fund for sponsor research and development projects in technology. The NGOs, old students' association, members of PTA (parents-teachers' association), and other financial blessed individuals should help to foster technology education by building schools, equipping laboratories, donating facilities, establishing trust funds, scholarships, alumni funds, endowment funds, etc.. More especially, they should provide avenues for self-employment.

\section{Conclusion}

This paper focused on education and more especially on science and technology education as the main vehicle for youth empowerment. It highlighted some of the psychosocial facilities that must be provided for the youths to be empowered technologically. The youths' responses proved to suggest that the psychosocial environment in our technology education institutions is not conducive for youth empowerment. The researcher then made some recommendations, which if implemented may help to improve the youth empowerment technologically.

\section{References}

Bojuwoye, D. (1985). Crisis in science classroom—-Poor enrolment of secondary school students in science subjects and its implications for science teachers. Journal of Science Teachers Association of Nigeria, 23(1\&2), 214-219.

Durojaiye, M. O. A. (1977). A new introduction to educational psychology. London: Evans Brothers. Nwokolo. (2002). Science, technology and poverty eradication. The Science Teacher Today, 1, 53-64. Onwuka. (1989). The status of teachers in Nigeria. CUDIMAC (Series 10). Nsukka: Atlanto Printer Co..

Ukeje, B. O. (1966). Education for social reconstruction. London \& Lagos: Macmillan. 